\title{
ORBWEAVERS' DIFFERENTIAL RESPONSES TO A TUNING-FORK
}

\author{
BY F. L. WELLS \\ Harvard Medical School
}

Patent factors in this behavior situation are, species and (developmental) age of the spider, position of the spider with reference to the nest, position of fork with reference to spider. Probably significant, but in the present circumstances less readily observed factors include general tensional state of spider (as nutritional), conditions of temperature and illumination (season, night and day; present observations mostly of daytime behavior), individual and sex differences.

Present reference is to females half grown or more, unless otherwise specified. Species observed include mainly the common: Epeira insularis (30), ${ }^{1} E$. trifolium (15), $E$. domiciliorum (8), E. stellata (6), E. cavatica (40), Argiope aurantia (40), A. trifasciata (15). Cavatica was observed in northern New Hampshire, others mainly in eastern Massachusetts. The earliest was of a young A. aurantia (7-7$35)$; the last of an old $A$. trifasciata (11-9-35). The fork was an ordinary Hartmann, designated C, 128. Normally it was sounded by striking smartly against the examiner's knee or forearm. To control-observations with the fork silent, all spiders compared were, with the rarest exceptions, inert (Peckham, p. 391, also Peters, '31, p. 698; Grünbaum, pp. 288-290). Neither did the retreat-dwellers respond to illumination by pocket flashlight, incidental to observation and photography at night. All observations were in the field, with minimal disturbance of spider's domestic economy.

The patterns of behavior distinguished, and the circum-

${ }^{1}$ Numerals are approximate number of individuals observed; some on one occasion only, others repeatedly, and over several weeks. Essential help in taxonomy and nomenclature is received from Professor Nathan Banks and Miss E. B. Bryant. 
stances in which they appeared, are in general as follows:

Dropping: As often reported, the spider, on the near approach of the fork, drops any distance from a few inches, to the substratum; returns after a very variable interval. In these observations not a characteristic response to the vibrating fork in any position. It is more so in smaller species, and is seen in exceptional individuals among the present. Among them, it is more usual in response to a relatively massive stimulus.

Folding: The spider immobilizes, with legs folded against body, the miscalled "death-feint." In Epeiras associated with dropping; not a normal response to present fork stimulation; as here seen, rather a product of other, and more massive accidental stimulus.

Shifting: The spider being at rest, moves the feet somewhat, but does not change its station. A response apparently arising when the fork, however presented, does not make on the receptors enough impression to set up any of the more differentiated responses noted below (cf. Schaxel, cited by Grünbaum, p. 287). Most strikingly seen in colonies of E. cavatica; a vibrating fork touched to a strand often elicited shifting through the colony generally, a few of the nearest making actual start for it.

Approaching: The spider resting at orb-center or in retreat, moves as to attack the fork held in contact with orb. Normal for all present species when resting at orb-center (Details on $E$. diademata, Peters, '31, p. 735). Less positive in long-matured (senescent?) individuals. For spiders in retreat (Boys; Barrows, p. 318) : First movement (to center) frequent for $E$. cavatica, occasional for $E$. trifolium, $E$. domiciliorum (probable individual difference) ; less frequent for $E$. insularis, though on occurrence, relatively violent.

Shaking and/or Arching: The spider, resting at orbcenter, arches legs, moving abdomen away from web; shakes web, sometimes for a whole minute, (function, cf. Barrows, p. 320 ; for $E$. diademata, Grünbaum, pp. 295, 297). Seen here most in early adult $A$. aurantia to fork held near venter, with orb between. Young A. trifasciata normally tilted the abdomen away from the fork, held to venter or dorsum.

Shuttling: The spider, resting at orb-center, moves 
through the web and assumes a corresponding position on the opposite side. Seen almost exclusively in A. aurantia, in response to fork presented to the dorsum, no web intervening. Young individuals accomplished it nimbly, the older slowly and clumsily; in mid-season it was little observed. Individual (occasional?) differences marked.

Spreading: The spider resting at orb-center, or elsewhere in the web, extends one or more pairs of legs, and holds them in extended position; in response to a vibrating fork near the body, but not in contact with the web. Seen most developed in E. insularis, less in E. trifolium and $A$. aurantia, E. domiciliorum, E. cavatica. In extreme cases (Epeira) all legs except one or two by which spider hangs, bend in opisthotonic spasm away from fork held to venter between them. If fork is held to dorsum, legs may similarly bend back towards fork. More noticed is orientation of venter towards fork (Peckham, p. 391, for E. diademata, Grünbaum pp. 292, 295), even through $180^{\circ}$, preserving tonic extension of legs. In aurantia, spreading did not generally involve more than the first two pairs and did not occur if the orb was between; in trifasciata it was little seen. Occasionally; spreading was observed (in E. trifolium and cavatica only) when fork was presented to venter of spider on back, folded in tonic immobility (Peckham, pp. 390392 ).

Reaching: Flexor movements alternating with extensor, to stimulus as in "spreading". Seen most in A. trifasciata, marked also in E. domiciliorum, E. stellata, and A. aurantia. These were relatively free, waving movements; in $E$. insularis they were often rapid twitches, through a smaller arc. Fork is not grasped in these movements though within easy reach, and often touched (Peckham, p. 391).

Seizing: The reaching movements are more effective, clinging to the fork, there is swathing and attempt to bite; on withdrawal of fork, spider remains with it, sometimes to complete detachment from web. Seen in larger, maturer orb-weavers generally, but marked occasional (individual?) differences. Besides this seizure of approximated fork not in contact with web (if web is between, spider climbs through), fork normally seized when vibrated in contact with web (details for $E$. diademata, Peters '31, pp. $721 \mathrm{ff.}$., 
Peters '33, also Grünbaum, p. 292), if sufficiently vibrating when spider reached it. Seizing movements normally ceased as vibration of fork subsided; might or might not be renewed upon reactivation of fork (cf. Peters as above; also Rabaud pp. 37, 41).

The above tuning-fork responses are much modified and decreased when the spider has a support other than the web (not especially in Grünbaum's observations, p. 296), or when the spider is not at rest. In the individuals compared (mostly cavatica, aurantia and Uloborus) there was little difference in the responses observed to a comparison fork of designated 256 rate (cf. Barrows, p. 321; Peckham, p. 391; Grünbaum, p. 295). To the much greater volume of sound from a dry-cell operated telegraph buzzer similarly presented, practically all individuals observed were inert (Peckham, p. 390, contrary to Savory, pp. 90-91; cf. also Peters, '31, p. 705).

\section{REFERENCES}

Barrows, W. M. The reactions of an orb-weaving spider, Epeira sclopetaria Clerck, to rhythmic vibrations of its web. Biol. Bull., 1915, 29, 316-332.

Boys, C. V. The influence of a tuning-fork on the garden spider. Nature, 1881, 23, 149-150.

Grünbaum, A. A. Ueber das Verhalten der Spinne (Epeira diademata) besonders gegenüber Vibratorischen Reizen. Psychol. Forschung, 1927, 9, 275-299.

Peckham, J. W. and Peckham, E. G. Some observations on the mental powers of spiders. J. Morphology, 1887, 1, 383-419.

Peters, H. Die Fanghandlung der Kreuzspinne. Experimentelle Analysen des Verhaltens. Zsch. f. vergl. Physiol., 1931, 15, 693749 .

Peters, H. Weitere Untersuchung über die Fanghandlung der Kreuzspinne (Epeira diademata Cl.) Zsch. f. vergl. Physiol., 1933, 19, $47-67$.

Rabaud, E. Recherches expérimentales sur le comportement de diverses Araignées. Année Psychol., 1922, 22, 21-57.

Savory, T. H. The biology of spiders. New York: Macmillan, 1928, pp. $\mathrm{xx}+376$. 

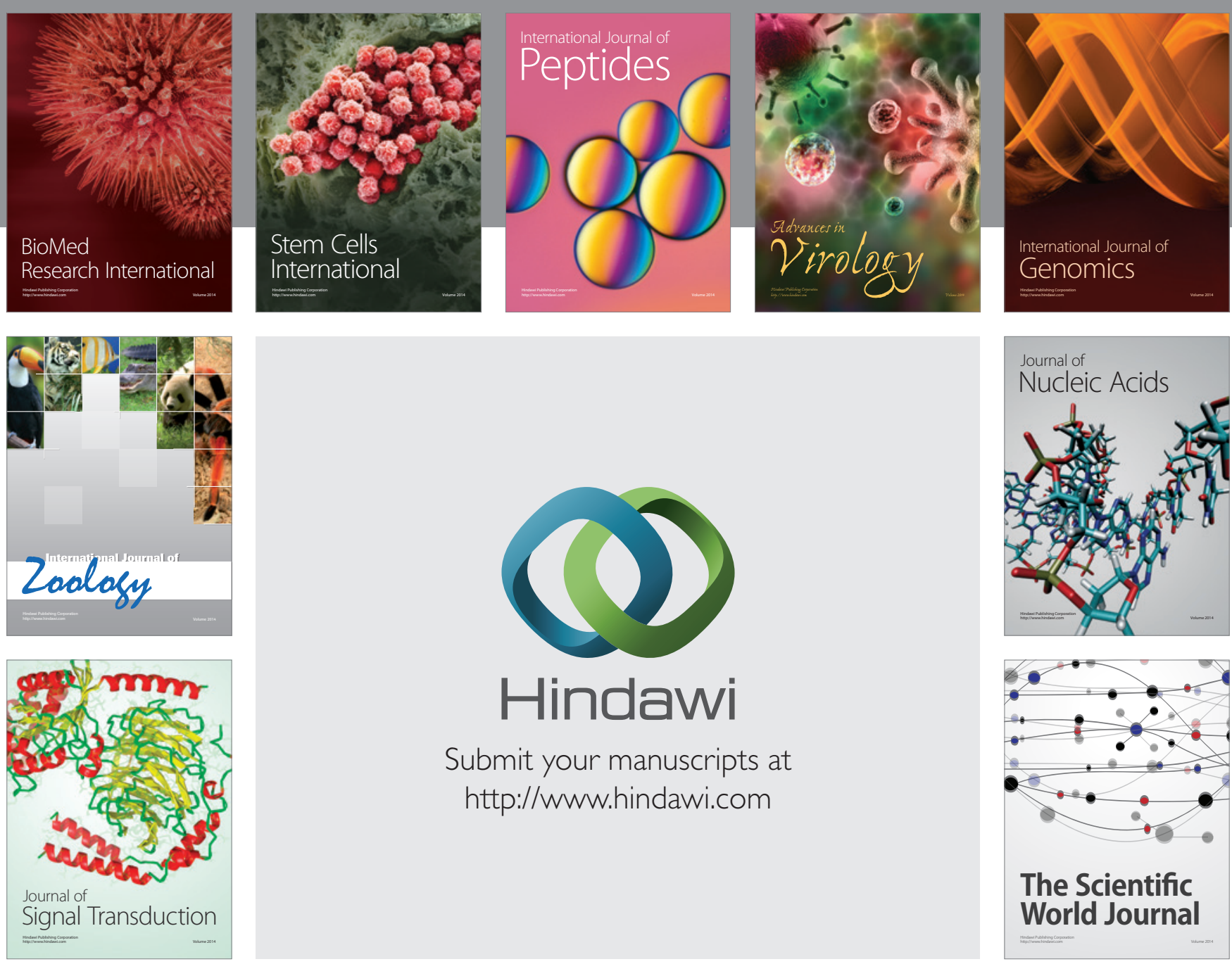

Submit your manuscripts at

http://www.hindawi.com
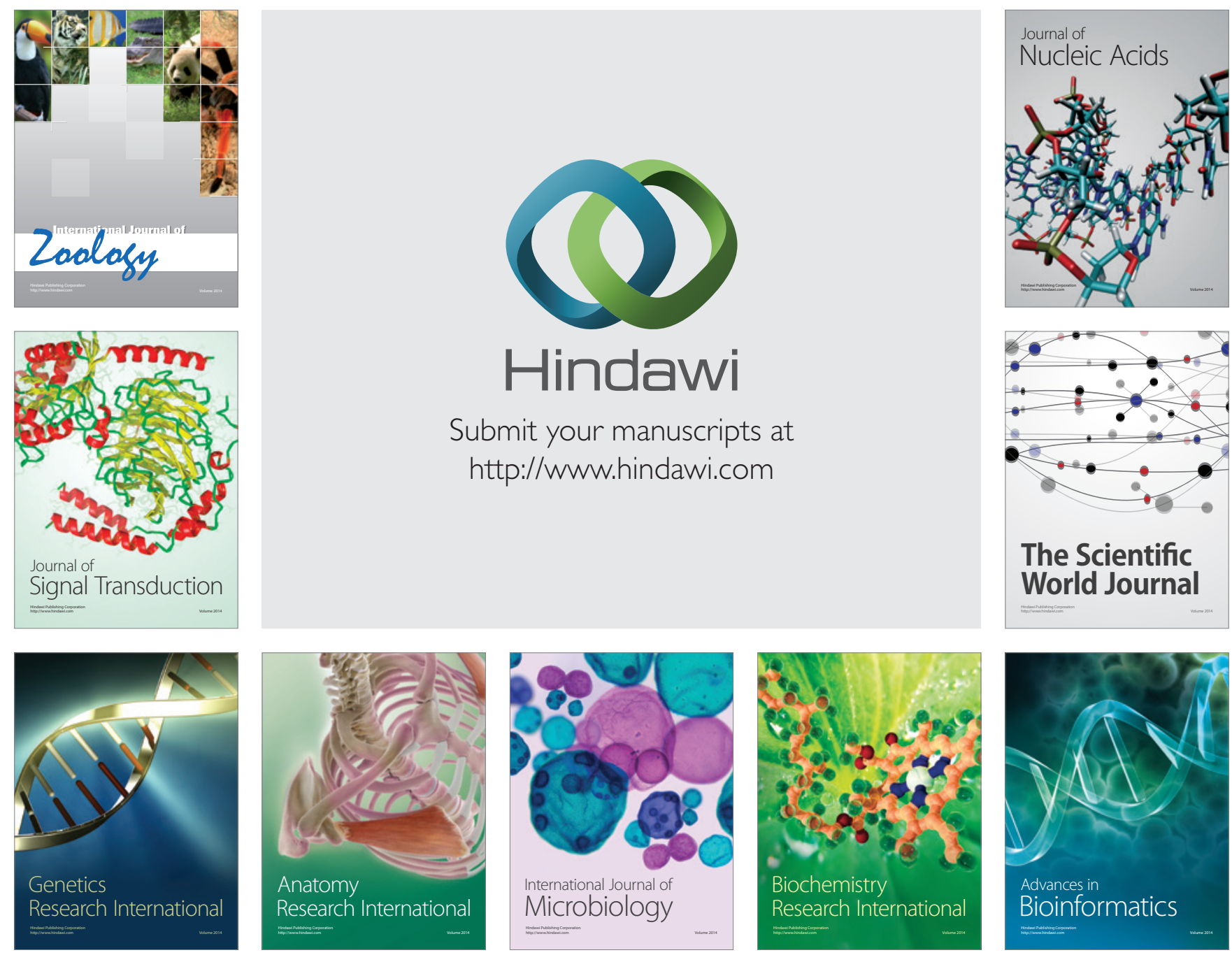

The Scientific World Journal
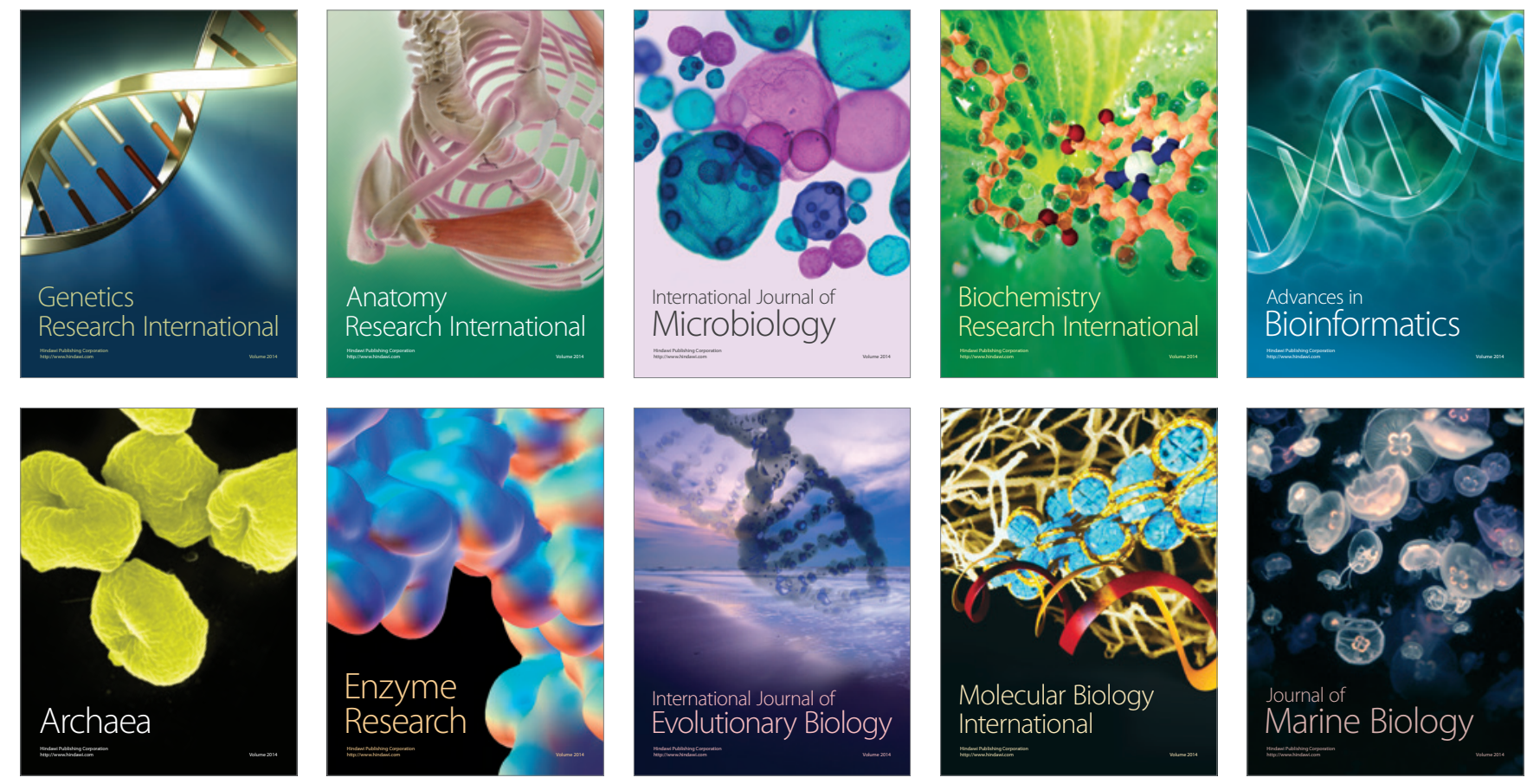